\title{
Evidence of cell deterioration in winterfat seeds during refrigerated storage
}

\author{
D. TERRANCE BOOTH, ROCHMAH AGUSTRINA, AND ROLLIN H. ABERNETHY
}

Authors are rangeland scientist, USDA, Agricultural Research Service (ARS), High Plains Grassland Research Station, Cheyenne, Wyo, 82009; former graduate student, and professor, Plant, Soil, and Insect Sciences Dept., University of Wyoming, Laramie, Wyo. 82071.

Abstract

Effective storage of wildland seeds helps alleviate supply shortages and mitigates variable production associated with annual weather patterns. The storage environment is critical for seeds like winterfat [Eurotia lanata (Pursh) Moq.) that rapidly lose viability under ambient conditions. Defining seed response to storage conditions is basic to effective seed storage programs. We used electron micrographs of freshly collected, and of stored winterfat seeds, with vigor tests to compare seedling vigor and to relate seed performance to seed cell biology as influence by; (a) seed age under known storage conditions, and (b) imbibition temperatures. We found that imbibition temperatures had little influence on the vigor of fresh seeds but significantly influenced aged seeds. Mitochondrial deterioration was evident in winterfat seeds stored 5-6 years at $5^{\circ} \mathrm{C}$, and in fresh, but incompletely hydrated seeds held at $20^{\circ} \mathrm{C}$. We recommend seeds be held at $-18^{\circ} \mathrm{C}$ or colder for long-term storage and that field seedings be done during the cold season to reduce the chance that incompletely hydrated seeds will be exposed to warm temperatures.

Key Words: Seed aging, mitochondria, vigor, imbibition, Eurotia, Ceratoides, Krascheninnikovia

Only in laboratory studies has it been possible precisely to separate effects on germination from effects on subsequent survival._John L. Harper (1977) in his book, 'Population Biology of Plants'.

Winterfat [Eurotia lanata (Pursh) Moq. ${ }^{1}$ and closely related species are important forage plants on the cold deserts of North America and Asia, but seeds of these species rapidly lose viability when stored at ambient conditions (Wilson 1931, Hilton 1941, Springfield 1968, 1974b). Springfield

Funding was provided by Partners for International Education and Training, Washington, D.C.; USDA-ARS; and the Wyoming Agricultural Experiment Station. Authors thank Carol Hearne, Wyoming State Veterinary Laboratory for helping us to obtain micrographs, and Dr. Patricia Berjak, University of Natal, Durban, South Africa for her invaluable assistance in interpreting micrographs of cell structure. We thank L.W. Griffith and H. Jansen for technical assistance and Drs R.L. Anderson, B.N. Smith, and A.G. Taylor for reviewing the manuscript Mention of trade or company names is for information only and does not imply an endorsement.

Manuscript accepted 24 Jul. 98.

\section{Resumen}

El almacenamiento efectivo de semillas silvestres ayuda aliviar la falta de suministro y mitigar la producción variable asociada con los patrones anuales de clima. El ambiente de almacenamiento es critico para semillas como las de "winter fat [Eurotia lanata (Pursh) Moq.]que rápidamente pierden viabilidad bajo las condiciones ambientales. El definir la respuesta de la semilla a las condiciones de almacenaje es básico para implementar programas efectivos de almacenamiento de semilla. Utilizamos micrográficas del microscopio electrónico de semillas recién cosechadas y semillas de "winter fat" almacenadas. Se utilizaron las micrográficas con pruebas de vigor para comparar el vigor de la plántula y relacionar el comportamiento de la semilla con la biología celular influenciado por: (a) la edad de la semilla bajo condiciones de almacenamiento conocidas y (b) las temperaturas de imbibición. Encontramos que la temperatura de imbibición tiene poca influencia en el vigor de semillas recién cosechadas, pero influencio significativamente el de las semillas envejecidas. La deterioro mitocondrial fue evidente en semillas de "winter fat" almacenadas durante 5-6 años a $5^{\circ} \mathrm{C}$ y en semillas frescas pero hidratadas incompletamente a $20^{\circ} \mathrm{C}$. Para el almacenamiento por largos periodos, recomendamos que las semillas deben ser conservadas $\mathrm{a}-18^{\circ} \mathrm{C}$ o temperaturas mas frías y que las siembras de campo sean hechas durante la época fría para reducir la probabilidad de que semillas hidratadas incompletamente sean expuestas a temperaturas calientes.

(1974b) recommended refrigeration for long-term storage and reported little germination from collections held at ambient temperatures for 8 years compared to $68 \%$ germination for seeds held at $5^{\circ} \mathrm{C}$. Although $5^{\circ} \mathrm{C}$ storage extends seed viability, its effect on seedling vigor is unknown.

Our objective was to determine if seed aging under $5^{\circ} \mathrm{C}$ storage reduced winterfat seedling vigor. Our hypothesis was developed from studies by Booth (1992), Booth and McDonald (1994), and Agustrina (1995). Booth (1992) reported seedling vigor was reduced by warm imbibition temperatures (Fig. 1). Booth and McDonald (1994) found that rapid

${ }^{1}$ Krascheninnikovia Gueldenstaedt. is the current synonymic favorite, replacing Ceratoides J.T. Howell. To call attention to the need to stabilize scientific nomenclature except where new evidence clarifies the phylogeny, we have retained Eurotia (Adanson 1763) which was used by most publications between 1840 and 1971. 

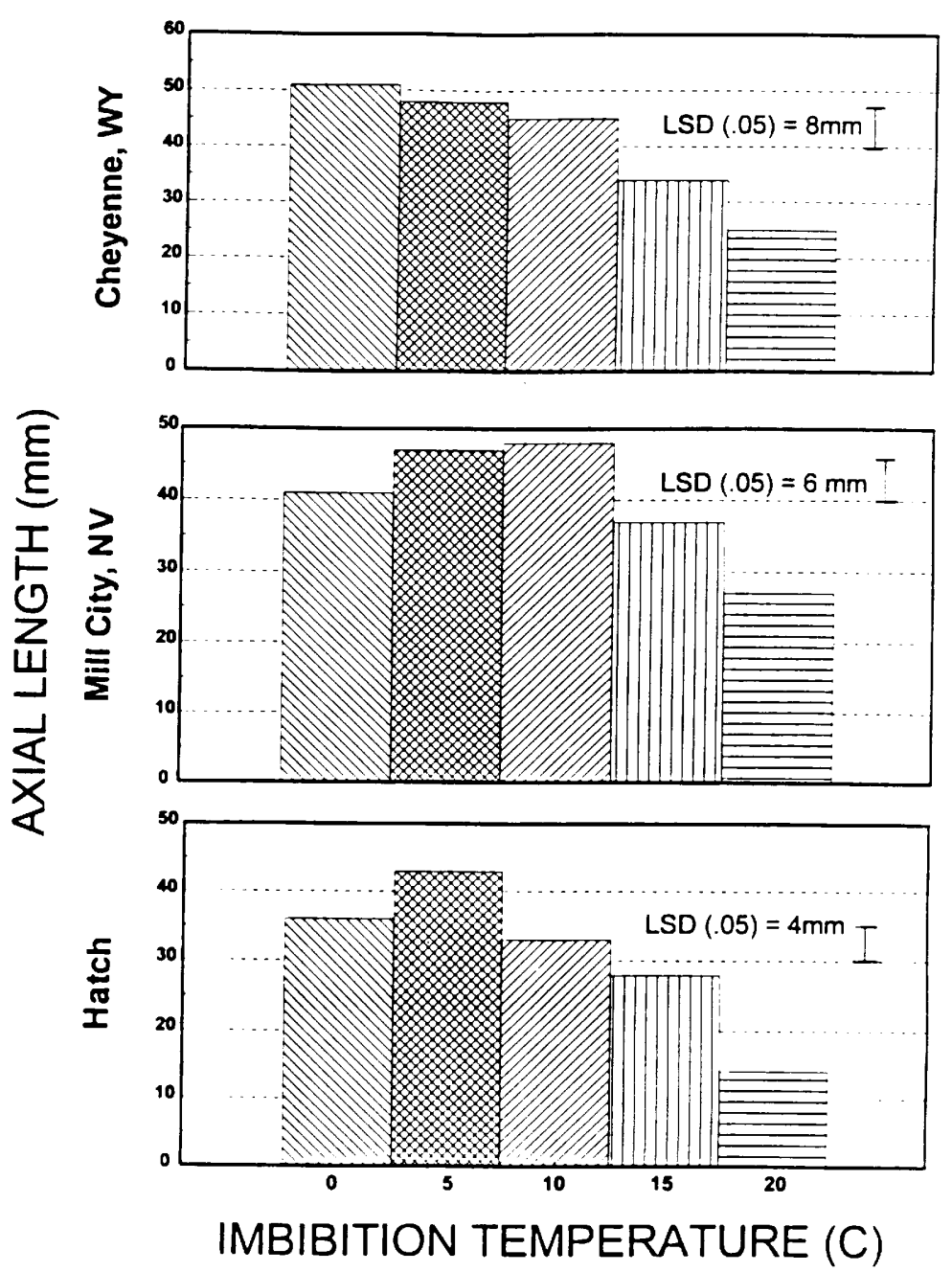

Figure 1. The effect of imbibition temperature on winterfat seedling vigor from seeds collected in Nevada and Wyoming, and from the released variety 'Hatch', as reported by Booth (1992).

imbibition of winterfat seeds at warm temperatures did not damage seed membranes. Agustrina (1995) found freshly harvested winterfat did not exhibit the imbibition-temperature response evident in the stored seeds used by Booth (1992). Because increases in respiratory activity during germination of other species have been associated with rapid development of mitochondrial ultrastructure, including rehydration of its membrane system (Nawa and Asahi 1973, Solomos et al. 1972), we hypothesized (1) that winterfat seeds stored more than 2 years at $5^{\circ} \mathrm{C}$ contained mitochondrial-ultrastructure changes that reduced seedling vigor and, (2) that imbibition temperatures affected winterfat seedling vigor by influencing mitochondrial hydration, metabolism and development in seeds stored more than 2 years at $5^{\circ} \mathrm{C}$.

\section{Methods and Materials}

\section{Plant Material}

Winterfat diaspores (seed-containing dispersal units) were collected in October, 1986 (Booth 1992); and from the same stand on the High Plains Grassland Research Station, Cheyenne, Wyo., (elevation of 1,909 m) in 1993 (Agustrina 1995). The diaspores of both collections were stored at room temperature for approximately 2 months, then stored at $5^{\circ} \mathrm{C}$ (Springfield 1974a). Using the methods described by Booth and Griffith (1984), a portion of the diaspores were threshed and seeds stored at $5^{\circ} \mathrm{C}$. The 1986 seeds were tested by Booth in 1989 and 1990. Seeds from diaspores collected in Cheyenne in 1993 were tested about 6 months after collection (Agustrina 1995).
Germination and Growth of 1986 and 1993 Seeds

Booth (1992) and Agustrina (1995) report tests for differences in seedling axial length (a measure of seedling vigor) due to imbibition temperature. We used these reports to compare seedling vigor from the 1986 and 1993 seeds by calculating the $95 \%$ confidence interval for mean axial lengths of seedlings from the 1986 seeds. We used the MSE from an ANOVA comparing seedling axial length by imbibition temperature for day 10 and for day 12 of incubation $(\mathrm{n}=75)$ (Booth, unpublished 1992 data). Confidence intervals were not calculated for the 1993 data because interactions among the several treatments prevented pooling of experimental units (Agustrina 1995). In their procedures Booth (1992) and Agustrina (1995) divided seeds into groups of 20 , weighed the groups to $0.01 \mathrm{~g}$, and humidified the seeds for 3 days at $2^{\circ} \mathrm{C}$ prior to imbibition to reduce imbibitional injury (Vertucci and Leopold 1984, Vertucci 1989). The seeds were then incubated on slant boards (Jones and Cobb 1963). The slant boards containing humidified seeds were placed in plastic boxes with tight fitting lids; the boxes filled to a depth of $5 \mathrm{~cm}$ with distilled water, then placed in incubators for 4 days at treatment temperatures that included 5 and $20^{\circ} \mathrm{C}$. All treatments were then incubated in the dark at $20^{\circ} \mathrm{C}$. The axial lengths of germinants were measured after 5, 7, 10, and 12 days of incubation using a digitizing tablet (Booth and Griffith 1994).

\section{Mitochondrial Ultrastructure Study}

Winterfat diaspores of the 1986 and 1993 Cheyenne collections were used for an electron microscope study of mitochondrial structure. The diaspores were threshed, the seeds weighed, and placed in a humidity chamber at 5 or $20^{\circ} \mathrm{C}$ until the seed weight reached 1.2 or 1.5 times the dry weight. After humidification, $1 \mathrm{~mm}$ was cut from the tip of the embryonic radicle and fixed in $5 \%$ glutaraldehyde at room temperature for 4 to 5 hours. For comparison, dry seeds were submerged in $1 \%$ glutaraldehyde in $0.1 \mathrm{M}$ sodium cacodylate $(\mathrm{pH}>$ 4) for 48 hours, then fixed in 5\% glutaraldehyde. Standard methods were used for specimen dehydration and 
mounting (Hayat 1986). The specimens were trimmed using an LKB ultratome (LKB Instruments, Inc., Rockville, Md.) For light microscopy, the 1.0 micron sections were cut using a Reichert Jung Ultracut (Reichert-Jung Optische Werke Ag, Hernalser Hauptstr, Wien, Austria), stained with $1 \%$ toluidine blue, and then observed under the light microscope. Using the light microscope we selected a representative area from the winterfat radicle tip for study by transmission electron microscope (TEM). A section approximately 79 nanometers thick was cut from the chosen area using the Reichert Jung Ultracut, stained with uranyl acetate and lead citrate, and then observed by TEM. A second group of representative cells were chosen from these TEM observations. Micrographs were obtained using an internally mounted camera on the TEM, the magnification was $50,700 \mathrm{x}$. Samples were cut from 3 different seeds in each treatment and 2-6 micrographs were made from each sample.

\section{Ratio of Mitochondrial Area to Cell Surface Area (MA/CA)}

Slides of TEM photos were used to determine the mitochondria number and a ratio of mitochondrial area to cell area (MA/CA). Relative area was measured by tracing projected images on tracing paper. Traced images were cut out, weighed, and the data used to calculate the ratio.

\section{Experimental Design and Statistical Analysis}

To compare MA/CA, mitochondrial number, and size of mitochondria we used a random design and the ANOVA procedure in SAS. Comparison of individual treatment means used the Least Significant Difference (LSD) for variables with a significant F-statistic (SAS 1985).

\section{Results}

\section{Germination and Growth of 1986 and 1993 Seeds}

Seedlings from the 1993 seeds had about twice the axial length of seedlings from the 1986 seeds (Table 1), and axial lengths from 1993 seeds did not fall within the axial-length confidence intervals of seedlings from 1986 seeds. These findings imply a significant dif-
Table 1. Seedling axial-length comparison between Cheyenne seeds collected in 1986 and tested between 1989-1990 vs. Cheyenne seeds collected in 1993 and tested in 1994. Seeds were imbibed at the temperature indicated for 4 days, then incubated at $20^{\circ} \mathrm{C}$. The $95 \%$ confidence interval is indicated for the 1986 seeds.

\begin{tabular}{cccc}
\hline \hline \multirow{2}{*}{ Temperature } & $\begin{array}{c}\text { Days } \\
\text { Measured }\end{array}$ & \multicolumn{2}{c}{$\begin{array}{c}\text { Mean Length } \\
\text { by Collection }\end{array}$} \\
\cline { 3 - 4 } & & 1986 & 1993 \\
\hline$--{ }^{\circ}$ C-- & $-------(\mathrm{mm})----------$ \\
5 & 10 & $48+4.8$ & 80 \\
& 12 & $48+4.7$ & 78 \\
20 & 10 & $25+4.8$ & 77 \\
& 12 & $25+4.7$ & 76
\end{tabular}

The seedling axial length means for 1986 seeds were obtained from earlier data (Booth, data on file). Means for 1993 are for seeds, at treatment temperature, without fungicide (Agustrina 1995).

ference in the seedling vigor between the 2 seedlots.

\section{Mitochondrial Ultrastructure}

Dry Seeds. Radicle-tip cells of dry seeds from 1986 and 1993 collections contained mitochondria with few cristae and numerous translucent areas in the mitochondria matrix. Hydration reconstituted radicle mitochondria for both 1986 and 1993 seeds.

Hydration at $5^{\circ} \mathrm{C}$. When hydrated at $5^{\circ} \mathrm{C}$ to the $20 \%$ moisture level, the mitochondria of 1993 seeds contained, (1) more distinct lipid bilayers of the outer membrane, (2) a greater number of cristae, and (3) a more uniformly dense matrix - typical for normal mitochondria of hydrated cells-than did cells from 1986 seeds (Fig. 2a versus 2b).

When hydrated at $5^{\circ} \mathrm{C}$ to $50 \%$ moisture content, mitochondrial ultrastructure of 1986 and 1993 seeds was similar (data not shown).

Hydration at $20^{\circ} \mathrm{C}$. Hydration to $20 \%$ moisture at $20^{\circ} \mathrm{C}$ resulted in 1993 seeds with thinner mitochondrial cristae than were observed in seeds hydrated at $5^{\circ} \mathrm{C}$ (data not shown); however, the mitochondrial matrix was more uniformly distributed. Hydration to 50\% moisture at $20^{\circ} \mathrm{C}$ produced 1993 seed with the most deteriorated mitochondrial structures seen among all treatments (Fig. 3). The outer membrane and cristae were completely degraded while in the 1986 seeds the outer membrane was partially degraded and the cristae structures could still be observed.

\section{MA/CA}

Neither imbibition temperature, collection year, moisture, nor their interactions significantly affected numbers of mitochondria. $P$ values ranged from 0.14 for the temperature $\mathrm{x}$ year interaction (Table 2) to 0.84 for moisture $\mathrm{x}$ year. However, the MA/CA ratio was affected by an imbibition-temperature $\mathrm{x}$ collection-year interaction $(\mathrm{P}=0.03)$. The greatest MA/CA ratio was observed from 1993 seeds imbibed at $20^{\circ} \mathrm{C}$ (Table $2)$. This was significantly greater $(\mathrm{P}<$ 0.05) than for 1986 seeds imbibed at $20^{\circ} \mathrm{C}$. The 2 collections did not differ when imbibed at $5^{\circ} \mathrm{C}$.

\section{Discussion}

\section{Mitochondrial Degradation}

Early metabolic activity, which begins near $20 \%$ seed moisture, consists of membrane reorganization, glycolysis, repair of organelles, and activation of enzymes in preparation for an increasing respiration rate and subsequent radicle emergence (Bewley and Black 1985). Loss of seedling vigor due to seed aging has been associated with a marked decline in soluble carbohydrate (Bermal-Lugo and Leopold 1992), increases in chromosomal aberration (Dimitrov 1994, Guiterrez et al. 1993), changes in ribosomal protein content (Zalewski 1985, Hallam et al. 1973), and abnormal mitochondrial structures (Hallam et al. 1973, Abu-Shakra and Ching 1967). Aging produces an accumulation of a free fatty acid mixture in

Table 2. Data for Cheyenne seeds collected in 1986 and 1993 showing the effects of temperature and collection year on total surface area of mitochondria per surface area of the cell (MA/CA) and on the number of mitochondria per cell. The temperature $x$ year interaction was significant for $\mathrm{MA} / \mathrm{CA}$ $(\mathbf{P}=\mathbf{0 . 0 3 5})$.

\begin{tabular}{cccc}
\hline \hline Temperature & Year & $\begin{array}{c}\text { Mean } \\
\text { MA/CA }\end{array}$ & $\begin{array}{c}\text { Mean number } \\
\text { Mitochondria }^{2}\end{array}$ \\
\hline NT (dry) & 86 & $0.268 \mathrm{a}^{2}$ & 31.67 \\
NT (dry) & 93 & $0.310 \mathrm{ab}$ & 33.67 \\
5 & 86 & $0.305 \mathrm{ab}$ & 40.50 \\
5 & 93 & $0.299 \mathrm{ab}$ & 37.34 \\
20 & 86 & $0.274 \mathrm{a}$ & 32.67 \\
20 & 93 & $0.373 \mathrm{~b}$ & 50.17 \\
\hline
\end{tabular}

${ }^{1}$ Dry and not treated

${ }^{2}$ Means with the same letter are not different as determined by $\mathrm{LSD}_{0.05}$. There were no differences in mitochondria numbers among treatments (P ranged from 0.14 for temperature $\mathrm{x}$ year, to 0.85 for moisture $\mathrm{x}$ year). 


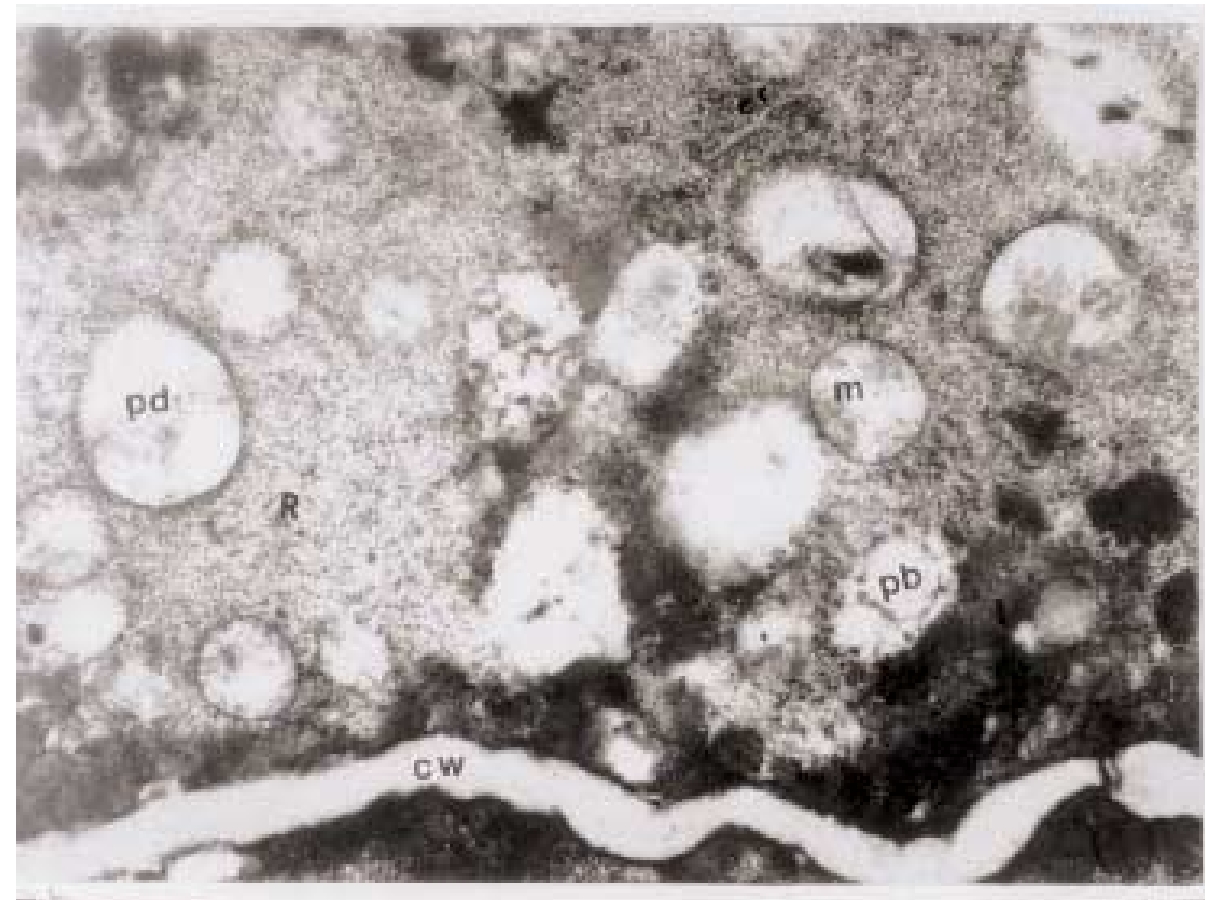

Fig. 2a

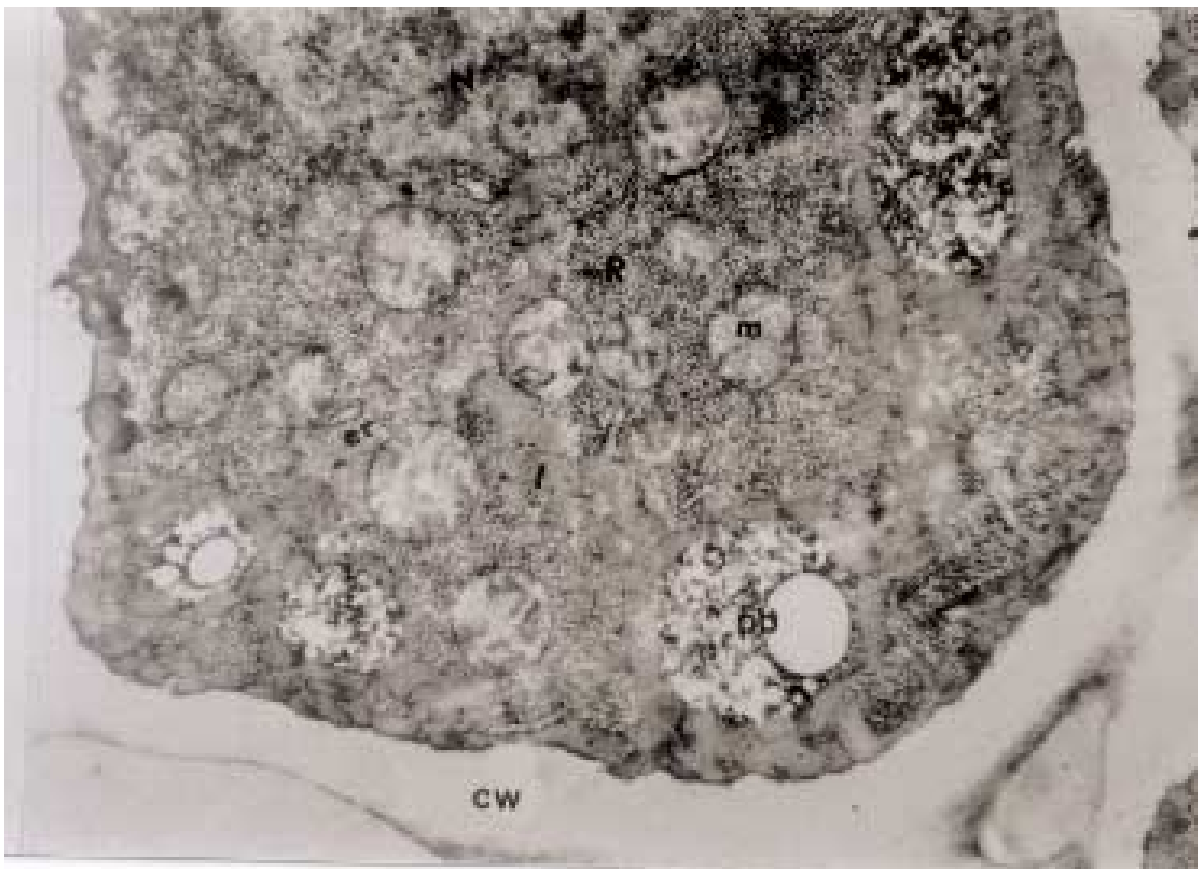

Fig. 2b

Fig. 2. The organelles of embryonic winterfat radicle cells $(50,700 \mathrm{x})$ of 1986 (a) and 1993 (b) seeds, hydrated at $5^{\circ} \mathrm{C}$ to $20 \%$ moisture. The organelles are represented as follows: (m) mitochondria; (cw) cell wall; (I) lipid body; (N) nucleus; (pd) plastid; (pb) protein body,(R) ribosome, and (er) endoplasmic reticulum.

mitochondrial membranes as a result of activation of phospholipase $\mathrm{A}_{2}$ (Luzikov et al. 1985; Nachbaur et al. 1972). This accumulation induces uncoupling of oxidative phosphorylation, reduces endogenous ATP levels, and leads to mitochondrial swelling (Luzikov et al. 1985). The characteristics of early mitochondrial degradation are dilution of the matrix, swelling and subsequent straightening of the folds formed by the inner membrane, rupture of the outer membrane, vacuolarization of the matrix, loss of the matrix content, and total disappearance of cristae (Luzikov et al. 1985); in short, a decrease in respiration capability and efficiency. Thus the lack of mitochondrial ultrastructure correlates with the low vigor of the 1986 seeds (Table 1).

\section{Effects of Seed Moisture and Temperature}

There were few differences between dry or hydrated seeds. This agrees with Baird et al. (1979) who also reported no appreciable differences between mitochondria in dry and imbibed radicle tissues.

Seed hydration at low temperature did produce differences in MA/CA between the 1986 and 1993 seeds as evident by the significant temperature $\mathrm{x}$ collectionyear interaction. The greater MA/CA for 1993 seeds imbibed at $20^{\circ} \mathrm{C}$, compared to that of 1986 seeds imbibed at $20^{\circ} \mathrm{C}$, and the lack of difference when these seeds were imbibed at $5^{\circ} \mathrm{C}$ (Table 2), suggest that early metabolic activity at $5^{\circ} \mathrm{C}$, maintained or repaired mitochondria in the 1986 seeds. Thus, these data provide a physiological explanation for Booth's (1992) finding that winterfat seedling vigor decreased with increasing imbibition tempertures (Fig. 1). The same explanation may apply to other chenopods shown to benefit from imbibition at temperatures suboptimal for germination (Haferkamp et al. 1990, Shaw et al. 1994).

Hydration at warm temperatures produced unexpected differences due to moisture content of the 1993 seeds. Why did these seeds show so much mitochondrial degradation at $50 \%$ moisture whereas the 1986 seed did not? Bain and Mercer (1966) reported that transportation of hydrolyzed food reserves from cotyledon cells of peas did not occur until the moisture level in the seeds reached more than $93 \%$. This suggests that translocation of hydrolyzed food reserves from winterfat seed-storage tissue may not have occurred at 50\% moisture.

Vartepetian et al. (1976) reported that ATP-regeneration was essential in maintaining the integrity of mitochondria in excised seedling tissues. Hodson et al. (1987) hypothesized that a delay in the development of mitochondrial structure may be related to the available energy supply in the seeds. The lack of activity 


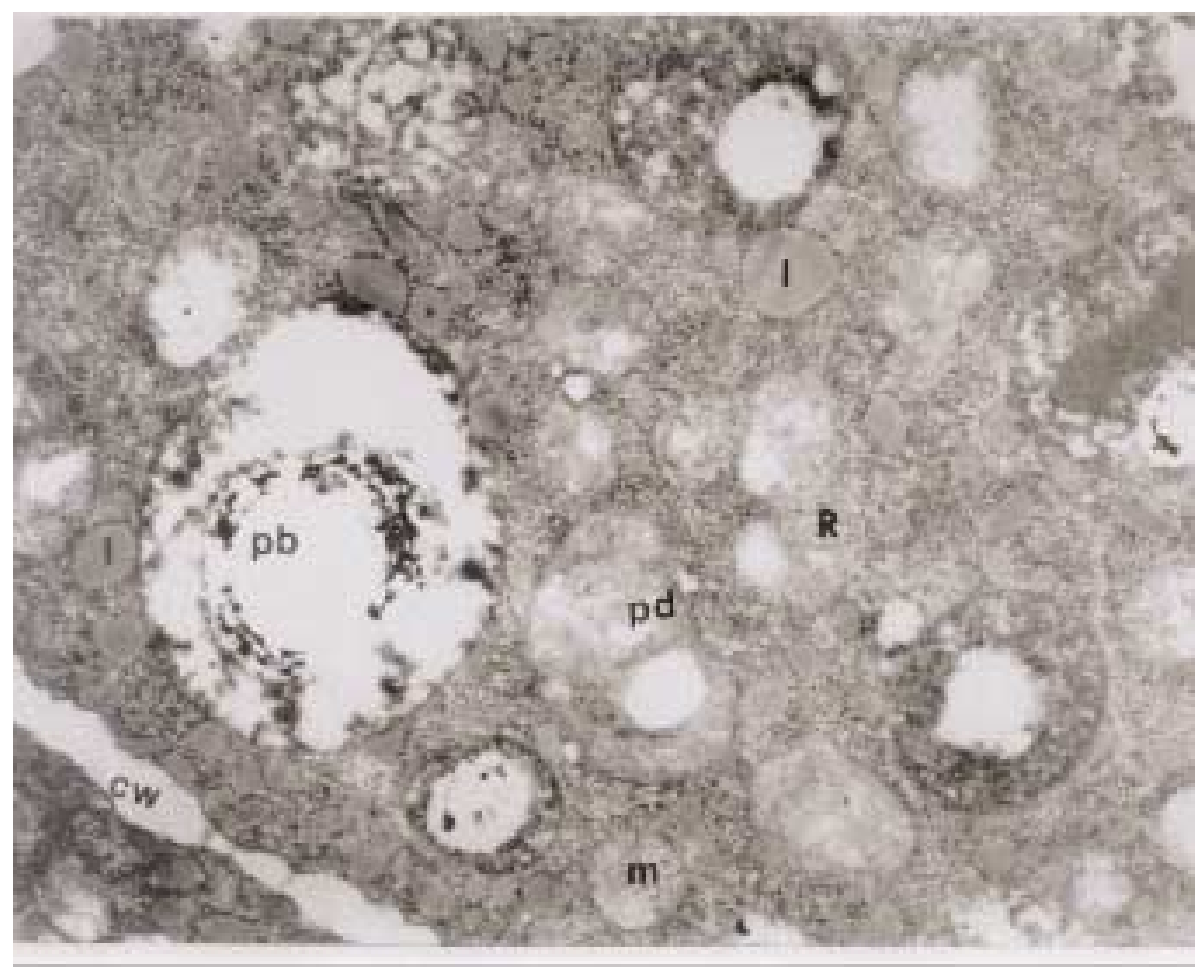

Fig. 3. The organelles of embryonic winterfat radicle cells $(50,700 x)$ in 1993 seed hydrated to $50 \%$ moisture at $20^{\circ} \mathrm{C}$. See Fig. 2 for organelle labeling information.

in the mitochondria of pea seedlings after their peak activity, was correlated with shrinking of the cotyledons (Malhotra et al. 1970).

So lack of an energy supply may have caused mitochondrial degeneration in the 1993 seed at $50 \%$ moisture. Would not this also occur in the 1986 seed? Aging may have reduced active catabolic enzymes in the 1986 seeds. Das and Sen-Mandi (1992) reported a decline in amylase activity of aged seeds. Declines in enzyme activity or in the cellular ability to synthesize proteins could indicate reduced catabolic activity. Thus, the 1986 mitochondria could be more degraded than in the 1993 seed at $20 \%$ moisture, then be less degraded at $50 \%$ moisture.

\section{Implication of Findings and Related Information}

The evidence is that storage at $5^{\circ} \mathrm{C}$ did not protect winterfat seeds from agerelated degradation. The seeds remained viable, but lost vigor. Other chenopod seeds stored at -12 to $-23^{\circ} \mathrm{C}$ were reported to have little loss of vigor after 22 years (Pack and Owen 1950). Roos (1989) recommended seeds be at $-18^{\circ} \mathrm{C}$ or lower for long term storage. but commented that "subfreezing temperatures appear slightly superior". However, he subsequently (Springfield 1974a) recommended refrigerated storage.

The severe degradation of mitochondria in 6-month-old seeds at 50\% moisture and $20^{\circ} \mathrm{C}$, suggests that fresh, partially hydrated seeds are at risk during periods of warm weather. We believe that the combination of warm soil temperatures (> $15^{\circ} \mathrm{C}$ ) and incomplete seed hydration could account for the failure of late-spring and summer winterfat seedings.

\section{Judging the Evidence}

Micrographs. The micrographs of the 1986 seed were made 3-4 years after the vigor test was conducted, and thus represent a more advanced stage of mitochondrial degradation than was present when the seeds were tested. The fact that the micrographs are of seeds that are older than the vigor test is perhaps fortunate since we may not have detected these gradual structural changes in 2year-old seeds.

Comparing Seedlots from Different Years. The Coefficients of Variation (Steel and Torrie 1980) for mean monthly temperature and precipitation for June through September, 1986 and 1993 at the High Plains Grasslands Research Station are smaller than the coefficients for the three 1993 seed collections (Cheyenne and Pine Bluffs, Wyo; and

Table 3. Climatological data and Coefficients of Variation for Cheyenne and Pine Bluffs, Wyo., and Sterling Colo. ${ }^{1}$

\begin{tabular}{|c|c|c|}
\hline & Mean Temperature & Mean Precipitation \\
\hline Cheyenne 1986 & $------\left({ }^{\circ} \mathrm{C}\right)-------$ & ------(mm)------- \\
\hline June & 18.2 & 62 \\
\hline July & 20.4 & 26 \\
\hline August & 19.6 & 39 \\
\hline Sept & 13.1 & 63 \\
\hline \multicolumn{3}{|l|}{ Cheyenne 1993} \\
\hline June & 15.0 & 84 \\
\hline July & NA & NA \\
\hline August & 18.4 & 56 \\
\hline Sept & 12.5 & 80 \\
\hline \multicolumn{3}{|l|}{ Pine Bluffs 1993} \\
\hline June & 15.8 & 66 \\
\hline July & NA & NA \\
\hline August & 19.1 & 22 \\
\hline Sept & 12.5 & 40 \\
\hline \multicolumn{3}{|l|}{ Sterling 1993} \\
\hline June & 19.9 & 52 \\
\hline July & 22.8 & 41 \\
\hline August & 22.5 & 50 \\
\hline Sept & 15.4 & 30 \\
\hline Coefficients of Variation for: & Temperature & Precipitation \\
\hline Cheyenne 1986 \& 1993 & 17.7 & 32.6 \\
\hline Chey., P. B., \& Sterl. 1993 & 20.9 & 37.7 \\
\hline
\end{tabular}

${ }^{1}$ National Oceanic and Atmospheric Administration $(1986,1993)$. Data for Sterling, Colorado was courtesy of the High Plains Climate Center, University of Nebraska, Lincoln (personal communication). 
Sterling, Colo.) tested by Agustrina (1995) (Table 3). Agustrina (1995) detected no significant differences in seedling axil length among the three 1993 seeds collections. This implies that differences in the seeds due to production year are small relative to aging differences, and are unlikely to confound our interpretation of the data.

Extrapolation from 1 Seed Source. We detected differences in basic cell biology that have been observed in seeds of other species. A basic process that occurs across species is not likely to change due to seed source within a species. Further, the 3 seed sources tested by Booth (1992) were all more than 2 years old and had been stored under similar conditions and gave similar responses to imbibition temperature. Finally, though Springfield (1968) did not grasp the importance of the differences between "refrigerated" and "freezer"-stored seeds, his observations add to the evidence that winterfat seed aging during $5^{\circ} \mathrm{C}$-storage is an important consideration for all winterfat seeds.

\section{Conclusion and Recommendations}

We conclude that storage of winterfat seeds at $5^{\circ} \mathrm{C}$ resulted in age-related degradation of seed mitochondria and other organelles during storage, and in a significant loss of seedling vigor. Also, that age-related degradation was the physiological reason for the seedlingvigor response to imbibition temperature found by Booth (1992) for 3 separate winterfat seed sources. We now believe that warm imbibition temperatures do not significantly reduce vigor of healthy seeds. However, incomplete hydration ( $>20 \%$ and $<90 \%$ seed moisture) at warm temperatures (near $20^{\circ} \mathrm{C}$ ) will result in rapid mitochondria degradation and loss of vigor. Also, imbibition at warm temperatures will reduce the vigor of seeds needing mitochondrial repair. For these seeds, cold imbibition reduces inefficient respiration and allows repair to proceed.

We recommend winterfat seeds be held $<-18^{\circ} \mathrm{C}$ to protect seed vigor during long term storage and, that the seeds be imbibed at 0 to $5^{\circ} \mathrm{C}$ as a standard laboratory practice. Cold imbibition does no damage to winterfat seeds and it does protect winterfat seed-vigor potential. For that reason we also recommend winterfat be seeded during the cold season.

\section{Literature Cited}

Abu-Shakra, S.S., and T.M. Ching. 1967. Mitochondrial activity in germinating new and old soybean seeds. Crop Sci. 7:115-118.

Agustrina, R. 1995. The influence of imbibition temperature on germination, mitochondrial structures, and proteins of winterfat (Ceratoides lanata (Pursh) J.T. Howell). Ph.D. dissertation. Univ. of Wyoming, Laramie, Wyo.

Bain, J.M. and F.V. Mercer. 1966. Subcellular organization of cotyledons in germinating seed and seedlings of Pisum sativum L. Aust. J. Biol. Sci. 19:69-84.

Baird, L.A.M., A.C. Leopold, W.J. Bramlage, and B.D. Webster. 1979. Ultrasructural modifications associated with imbibition of the soybean radicle. Bot. Gaz. 140:371-377.

Bermal-Lugo, I. and A.C. Leopold. 1992. Changes in soluble carbohydrates during seed storage. Plant Physiol. 98:1207-1210.

Bewley, J.D. and M. Black. 1985. Seeds: physiology of development and germination. Plenum Press. New York and London.

Booth, D.T. 1992. Seedbed ecology of winterfat: imbibition temperature affects postgermination growth. J. Range Manage. 45:159-164.

Booth, D.T. and L.W. Griffith. 1984. Evaluation of air threshing for small lots of winterfat fruits. J. Range Manage. 37:287-287.

Booth, D.T. and L.W. Griffith. 1994. Technical note: Measuring post-germination growth. J. Range Manage. 47:503-504.

Booth, D.T. and M.B. McDonald. 1994. Cation concentration in post-imbibed winterfat seeds as influenced by imbibition temperature. J. Range Manage. 47:485-488.

Das, G. and S. Sen-Mandi. 1992. Scutellar amylase activity in naturally aged and accelerated aged wheat seeds. Ann. Bot. 69:497-501.

Dimitrov, B. D. 1994. Types of chromosomal aberrations induced by artificial seed ageing in Crepis capillaris. Cytobios. 77:107-114.

Gutierrez, G., F. Cruz, J. Moreno, V.A. Gozales-Hernandez, and J.M. VazquezRamos. 1993. Natural and artificial seed ageing in maize: Germination and DNA synthesis. Seed. Sci. Res. 3:279-285.

Haferkamp, M.R., D.C. Ganskopp, K.L. Marietta, and B.W. Knapp. 1990. Environmental influences on germination of utricles and seedling establishment of 'immigrant' forage kochia. J. Range Manage. 43:518-522.

Hallam, N.D, B.E. Robert, and D.J. Osborn. 1973. Embryogenesis and germination in rye. III. Fine structure and biochemistry of the non-viable embryo. (Secale cereale L.). Planta 110:279-290.

Harper, J.L. 1977. Population biology of plants. Academic Press. New York.

Hayat, M. A. 1986. Basic technique for transmission electron microscopy. Academic Press Inc. Orlando, Fla.. p. 347.

Hilton, J. W. 1941. Effects of certain microecological factors on the germinability and early development of Eurotia lanata. Northwest Sci. 15:86-92.

Hodson, M.J., L. Di Nola, and A.M. Mayer. 1987. The effect of changing temperature during imbibition on ultrastructure in germinating pea embryonic radicle. J. Exp. Botany. 38:525-534.

Jones, L.G. and R.D. Cobb. 1963. A technique for increasing the speed of laboratory germination testing. Proc. Assc. Offic. Seed Analysts. 53:144-160.

Luzikov, V.N., A.V. Galkin, and D.B. Roodyn. 1985. Mitochondrial biogenesis and breakdown. Consultant Bureau. New York.

Malhotra, Surjit S. and Mary Spencer. 1970. Changes in the respiratory, enzymatic, and swelling and contraction properties of mitochondria from cotyledons of Phaseolus vulgaris L. during germination. Plant Physiol. 46:40-44.

Nachbaur, J., A. Colbeau, and P.M. Vignais. 1972. Distribution of membrane-confined phospholipases $\mathrm{A}$ in the rat hepatocyte. Biochem. Biophys. Acta. 274:426-446.

National Oceanic and Atmospheric Administration. 1986. Climatological Data-Wyoming. Volume 92, Numbers $6,8,9$.

National Oceanic and Atmospheric Administration. 1993. Climatological Data-Wyoming. Volume 102, Numbers 6, 8, 9 .

Nawa, Y. and T. Asahi. 1973. Relationship between the water content of pea cotyledons and mitochondrial development during early stage of germination. Plant Cell Physiol. 14:607-613.

Pack, D.A. and F.V. Owen. 1950. Viability of sugar beet seed held in cold storage for 22 years. Amer. Soc. Sugar Beet Technol. Proc. 6:127-129.

Roos, E.E. 1989. Long-term seed storage. Plant Breeding Reviews 7:129-158.

SAS. 1985. SAS User's Guide: Statistical Analysis System Institute, Inc. Cary, N. C. Shaw, N.L., M.R. Haferkamp, and E.G. Hurd. 1994. Germination and seedling establishment of spiny hopsage in response to planting date and seedbed environment. J. Range Manage. 47:165-174. 
Solomos, T., S.S. Malhotra, S. Prasad, S.K. Malhotra, and M. Spencer. 1972. Biochemical and structural changes in mitochondria and other cellular components of pea cotyledons during germination. Can. J. Biochem. 50:725-732.

Springfield, H.W. 1968. Cold storage helps winterfat seeds retain viability. J. Range Manage. 21:401-402.

Springfield, H.W. 1974a. Eurotia lanata (Pursh) Moq. p. 398-400 In: C.S. Schopmeyer (Tech-Coord.) Seeds of Woody Plants in the United States, Ag. Handbook No. 450. Forest Service, USDA, Washington, D.C.
Springfield, H.W. 1974b. Winterfat seeds viable after 8 years refrigerated storage. J. Range Manage. 27:78.

Steel, R.G.D. and J.H. Torrie. 1980. Principles and procedures of statistics. McGraw-Hill Book Company. N.Y.

Vartepetian, B.B., I.N. Andreeva, and G.J. Kozlova, 1976. The resistance to anoxia and the mitochondrial fine structure of rice seedling. Phytochemistry 88:215-225.

Vertucci, C.W. 1989. The effects of low water content on physiological activities of seeds. Physiol. Plant. 77:172-176.
Vertucci, C.W. and A.C. Leopold. 1984. Bound water and its relation to respiration and imbibitional damage. Plant Phyiol. 75:114-117.

Wilson, C.P. 1931. The artificial reseeding of New Mexico ranges. N. Mex. Agr. Exp. Sta. Bull. 189.

Zalewski, K. 1985. The metabolism of aged seeds the formation of polyribosomes in the embryos of germinating rye grains of different viability. Acta Soc. Bot. Pol. 54(4):417-427. 